\title{
A dual-process model of diversity outcomes: The case South African police service in the Pretoria area
}

\begin{tabular}{|c|c|}
\hline $\begin{array}{l}\text { Authors: } \\
\text { Leon T.B. Jack } \\
\text { Fons J. R. van } \\
\text { Davey H. Mol }\end{array}$ & $\begin{array}{l}\text { de Vijver } \\
\text { di,3 } \\
\text { koane }\end{array}$ \\
\hline \multicolumn{2}{|c|}{$\begin{array}{l}\text { Affiliations: } \\
{ }^{1} \text { Economic and Management } \\
\text { Sciences Faculty, North-West } \\
\text { University, Potchefstroom } \\
\text { Business School, South Africa }\end{array}$} \\
\hline \multicolumn{2}{|c|}{$\begin{array}{l}\text { ²Department of Psychology, } \\
\text { Tilburg University, } \\
\text { the Netherlands }\end{array}$} \\
\hline \multicolumn{2}{|c|}{$\begin{array}{l}{ }^{3} \text { WorkWell Research Unit for } \\
\text { Economics and Management } \\
\text { Sciences, North-West } \\
\text { University, South Africa }\end{array}$} \\
\hline \multicolumn{2}{|c|}{$\begin{array}{l}\text { Correspondence to: } \\
\text { Leon Jackson }\end{array}$} \\
\hline \multicolumn{2}{|c|}{$\begin{array}{l}\text { Email: } \\
\text { leon.jackson@nwu.ac.za }\end{array}$} \\
\hline \multicolumn{2}{|c|}{$\begin{array}{l}\text { Postal address: } \\
\text { North-West University, } \\
\text { Private Bag X6001, } \\
\text { Potchefstroom 2520, } \\
\text { South Africa }\end{array}$} \\
\hline \multicolumn{2}{|c|}{$\begin{array}{l}\text { Received: } 18 \text { Oct. } 2012 \\
\text { Accepted: } 11 \text { June } 2013 \\
\text { Published: } 02 \text { Sept. } 2013\end{array}$} \\
\hline \multicolumn{2}{|c|}{$\begin{array}{l}\text { How to cite this article: } \\
\text { Jackson, L.T.B., Van de } \\
\text { Vijver, F.J.R., \& Molokoane, } \\
\text { D.H. (2013). A dual- } \\
\text { process model of diversity } \\
\text { outcomes: The case South } \\
\text { African police service } \\
\text { in the Pretoria area. SA } \\
\text { Journal of Human Resource } \\
\text { Management/SA Tydskrif vir } \\
\text { Menslikehulpbronbestuur, } \\
\text { 11(1), Art. \#504, } 13 \text { pages. } \\
\text { http://dx.doi.org/10.4102/ } \\
\text { sajhrm.v11i1.504 }\end{array}$} \\
\hline \multicolumn{2}{|c|}{$\begin{array}{l}\text { Copyright: } \\
\text { (C) 2013. The Authors. } \\
\text { Licensee: AOSIS } \\
\text { OpenJournals. This work } \\
\text { is licensed under the } \\
\text { Creative Commons } \\
\text { Attribution License. }\end{array}$} \\
\hline \multicolumn{2}{|l|}{ Read online: } \\
\hline 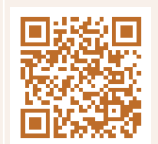 & $\begin{array}{l}\text { Scan this QR } \\
\text { code with your } \\
\text { smart phone or } \\
\text { mobile device } \\
\text { to read online. }\end{array}$ \\
\hline
\end{tabular}

Orientation: The study addresses the question of how employees of the South African Police Service (SAPS) cope with intercultural relations in an increasingly diverse organisation.

Research purpose: A dual-process model of diversity outcomes was tested in which a distinction is made between a positive (work-related) stream that links positive diversity conditions through active coping to work outcomes and a relatively independent (healthrelated) stream of negative antecedents, mediating passive coping skills and ill-health related outcomes

Motivation for the study: To test the viability of a dual-process model to understand diversity outcomes in the workplace.

Research design, approach and methods: A convenience sample $(n=158)$ was recruited from members of the SAPS in Gauteng, using a cross-sectional design. Instruments used in previous acculturation research were adapted to measure contextual factors, coping and diversity outcomes.

Main findings: A very good fit for the proposed hypothetical model was found. Approach coping partially mediated the relationship between positive acculturation conditions and the subjective experience of work success whereas avoidance coping fully mediated the relationship between discrimination, and ill-health symptoms are related to ill-health symptoms.

Practical/managerial implications: Mainstream-facilitating conditions and discrimination influence individual coping styles, which in turn impact on ill-health and the subjective experience of work success. In addition, ill-health also impacts negatively on work-success experiences amongst the sampled SAPS members. It would thus make sense for the SAPS to sanction discrimination.

Contribution/value added: A variation of the mediated dual-process model for diversity (Jackson \& Van de Vijver, in press), using coping strategies as mediators was supported. The model adds new insights in diversity in organisations.

\section{Introduction}

South Africa is culturally diverse. So are its organisations. Employees have to deal with this diversity in two ways. The first involves the plural composition of the workforce. South-African workers at all levels have colleagues from other cultural groups at the same or different rank. The second involves differences between the employee's home culture and the culture of the workplace. There is a disparity between the cultures of the home and the workplace for many South Africans. The business world as currently conceptualised and structured in most South African corporations is generally cast in a Eurocentric mould (Khoza, 2002). The differences between Eurocentric and Afrocentric styles are big; the latter focus more on interpersonal relations. As a consequence, many Black groups (although considered as the mainstream from a political perspective based on their ability to mobilise votes) experience their economic (work) life as belonging to a different culture. If little or no consideration is given to indigenous cultures and worldviews, there is a serious danger of imposing the business culture on employees and alienating them from their organisations.

South Africa has a long history of discrimination, but the dawn of the democratic dispensation after 1994 saw the introduction of a number of initiatives aimed at addressing past injustices such the use of affirmative action practices in appointments and promotions in especially the private sector. The introduction of these practices unfortunately also led to newspaper headlines such as 'Whites not truly welcome', 'Union challenges prisons AA police', 'Solidarity in new affirmative action case' and 'Union goes to court over $\mathrm{AA}^{\prime}$ '. Two decades after the first democratic elections, South Africans are still struggling with intercultural contact, especially in the workplace. 
Dynamics involved in intercultural contact or interaction are issues typically covered in diversity and acculturation studies.

The primary objective of this research was to explore the impact of acculturation context and individual variables on diversity outcomes of SAPS members. Theoretical models of acculturation that have been developed in cross-cultural psychology are employed. The core constructs of the study are constituted by positive or facilitating acculturation context variables and discrimination or a restraining acculturation contextual variable as antecedent variables, approach and avoidance coping strategies as intervening variables and subjective work success and ill-health symptoms as outcome variables.

\section{Background of the dual-process model of diversity outcomes}

The current study addresses the question of how employees of the South African Police Service (SAPS) cope with intercultural relations in their increasingly diverse organisation. Knowledge about how individuals cope with interpersonal problems is important because people spend a large portion of their time interacting with others (Carpenter \& Scott, 1992). Negative social interaction and interpersonal stressors have been found to be negatively related to psychological and physical well-being (Ewart, Taylor, Kraemer \& Agras, 1991; Herbert \& Cohen, 1993; Walen \& Lachman, 2000). Walen and Lachman (2000) provided evidence to the effect that social tension is negatively related to health, life satisfaction and positive mood whilst it is positively related to health problems and negative mood. The theoretical framework of the present study draws on mediation models of coping (Folkman \& Lazarus, 1988), acculturation (Arends-Tóth \& Van de Vijver, 2000, 2006), and the Job Demands Resources model (Demerouti, Bakker, Nachreiner \& Schaufeli, 2001). In this study the focus was on whether it would be possible to understand acculturation and diversity outcomes such as subjective experiences of work success and ill-health using a coping perspective in a dual-process framework linking acculturation demands and resources. Description of the relevant theoretical frameworks follows below.

\section{The Job Demands-Resources model}

The Job Demand-Resources (JD-R) model tries to explain how employees combine job demands and job resources in processes of work wellness and burnout. The model assumes that two underlying psychological processes play a role in burnout and disengagement (Demerouti, Bakker, Nachreiner \& Schaufeli, 2001). Schaufeli and Bakker (2004) extended the JD-R model by including engagement and by adding indicators for health impairment and organisational withdrawal in the comprehensive burnout and engagement (COBE) model. The COBE model also assumes that the energetic process links job demands with health problems via burnout whilst the motivational process links job resources via work engagement with organisational outcomes. The JD-R model has effectively been used to explain organisational commitment (Jackson, Rothmann \& Van de Vijver, 2006), job satisfaction (Martinussen, Richardsen \& Burke, 2007), absenteeism (Schaufeli \& Bakker, 2004), performance (Xanthopoulou, Bakker, Demerouti \& Schaufeli, 2009) and workplace bullying (Van den Broeck, Baillien \& De Witte, 2011). More recently, the basic premises of the JD-R model have also been extended to a dual-process model to explain adaptation in the acculturation process (Jackson \& Van de Vijver, in press), psychosomatic complaints (Hakanen, Bakker \& Schaufeli, 2006), as well as mental health, including depression (Antaramian, Huebner, Hills \& Valois, 2010; Hakanen, Schaufeli \& Ahola, 2008). These studies demonstrated that the JD-R model is informative in explaining workers' health as well as a meaningful and insightful framework for understanding organisations' productivity.

\section{Acculturation}

Acculturation is a process of interaction of cultures, and it can be defined as what happens when groups of individuals with different cultures come into continuous first-hand contact with subsequent changes in the original culture patterns of either or both groups (Redfield, Linton \& Herskovits, 1936). A bi-dimensional acculturation model is adopted here which postulates that ethnic and host cultures constitute two independent dimensions and that the adherence to the one may not affect adherence to the other (Berry, 1997). When considered in conjunction, the independent dimensions yield four acculturation strategies at the disposal of mainstreamers, namely melting pot (full adaptation to the mainstream culture whilst giving up the home culture), multiculturalism (maintenance of home culture and adopting the mainstream culture), segregation (full maintenance of the home culture, mainstream culture is not adopted) and exclusion (adherence to neither culture). From the perspective of immigrants, these four are called assimilation, integration, separation and marginalisation, respectively.

The present research makes use of the above frameworks of acculturation to explain the experience of diversity in the SAPS. The discussion of antecedent, intervening and outcome variables are restricted to those that were deemed relevant for understanding diversity in SAPS and that were addressed in the present study. It is argued that Acculturation and multiculturalism are fruitful frameworks to study diversity in South Africa because extant concepts and models of intercultural contact and acculturation can be used to describe intercultural contact and acculturation and the SAPS's organisational culture and to understand the structure and dynamics of multicultural teams in SAPS.

\section{Antecedent factors}

The circumstances in which people have to cope with diversity are important for process and outcomes (Berry, 1997; Bourhis, Moise, Perreault \& Senecal, 1997; Jackson, Van de 
Vijver \& Ali, 2012; Jackson, Van de Vijver \& Burckard, 2011). Bourhis et al. (1997) stressed the importance of the intergroup attitudes preferred by the majority as determinants of diversity outcomes. Jackson, Van de Vijver and Ali (2012) pointed to the importance of intergroup attitudes preferred by the (majority and) minority ethnic groups as determinants of diversity outcomes. In this study, acculturation antecedents are multiculturalism, tolerance (positive majority context), ethnic vitality and social support (positive ethnic context) and discrimination (negative majority context).

\section{Multiculturalism}

Scholars from various disciplines have attempted to define the construct of multiculturalism. The definition differs somewhat across disciplinary perspectives. Psychologists, for example, define the construct at the micro-level to include elements of tolerance and respect whilst organisational scholars define it at a meso-level to include elements of a diversity climate. Demographers and sociologists tend to define multiculturalism at a macro-level as involving a society with multiple cultures. These differences in disciplinary perspectives gave rise to four categories of definitions, depending on whether they were based on relativism, polarities, typologies or dimensions (Munusamy, 2009). The first two perspectives have been quite controversial. For example, there has been quite some discussion on the desirability and feasibility of creating a coherent society based on multiple ethnic groups that agree on basic values of the society. A good example is the discussion in Western Europe on the need for all groups to accept basic freedoms, civic attitudes and democratic rights as organising principles of society. In line with the theoretical perspective (acculturation and organisational psychology), a typological and dimensional approach to multiculturalism, common in psychology was adopted. Multiculturalism is viewed as one of four possible acculturation strategies (type) according to Berry (1997). Therefore, in this study, multicultural norms (policy to management of diversity dimension) relate to rules prescribing behaviour in a multi-ethnic context where multicultural practices (implementation dimension) highlight examples of behaviour that are related to these rules, such as respect for differences, in line with the dimension or level approach for investigating and understanding the concept (Eldering, 1996; Vertovec, 1996).

Psychological research (e.g. Breugelmans \& Van de Vijver, 2004) shows that, in as much as a multicultural ideology is perceived as a solution for managing plural societies, support for it should not be taken for granted and differs between both individuals and ethnic groups. Minorities, that stand to gain from this policy, are usually more supportive than the majority or dominant group; the latter may see these polices as a threat to their dominant position. Support for multiculturalism is negatively related to ethnocentrism, perceived ethnic threat, intergroup competition, exclusion of immigrants in the larger society (Citrin, Sears, Mutse \& Wong, 2001; Raijman, Semyonov \& Schmidt, 2003; Semyonov, Raijman, Tov \& Schmidt, 2004; Verkuyten, 2005; Verkuyten
\& Brug, 2004) and preference for ethnic integration strategies, work success and the reduction of ill-health symptoms in the workplace (Jackson, Van de Vijver \& Ali, 2012).

\section{Tolerance}

Tolerance, acceptance, being open, understanding and respect are important aspects of multiculturalism. Tolerance is related to the principle of reciprocity and amounts to showing respect for the rights, opinions and practices of others or not imposing your views on others (Munusamy, 2009). This conceptualisation of the interrelatedness of tolerance and multiculturalism is very much in line with the requirements for multiculturalism according to Berry and Kalin (1995). They point to the fact that intercultural contact and participation in society by all groups and general support for cultural maintenance by immigrants, low levels of prejudice and intolerance in the population (no discrimination) and positive attitudes towards each other should exist amongst the diverse ethno-cultural groups. Furthermore, a degree of attachment to the larger society should exist without the derogation of its essential ethnocultural groups. The importance of tolerance or the absence of prejudice and discrimination is perhaps best described by the negative impact of racism and discrimination on wellbeing in the acculturation process as demonstrated in various studies (Gee, Ro, Shariff-Marco \& Chae, 2009; Jackson, Van de Vijver \& Burckard, 2011; Jackson \& Van de Vijver, in press).

\section{Discrimination}

In its most simple sense, discrimination refers to any practices and policies that advantage or benefit one group at the expense of another or inequitable treatment based on group membership. Discrimination, individual or group-based, involves a group of individuals being given preferential treatment over others (Cascio, 2010). South Africa has a historical legacy of deeply entrenched racial discrimination. However, this changed after 1994 with the adoption a New Constitution that:

... prohibits unfairly discriminate directly or indirectly against anyone on one or more grounds, including race, gender, sex, pregnancy, marital status, ethnic or social origin, colour, sexual orientation, age, disability, religion, conscience, belief, culture, language and birth (RSA, 1996, p.3).

Many previously advantaged members perceive measures like affirmative action that are aimed at enhancing the position of previously disadvantaged groups as reverse discrimination (Herman, 2000). The extensive use of affirmative action in promotions in especially the public sector has recently seen an increase in discrimination cases against state departments such as SAPS, especially by White people, Indian people and Coloured people. The experience of discrimination may have short or long-term consequences for the victims.

The effects of perceived discrimination on well-being include psychological effects such as higher stress levels, anxiety and depression (Huynh, Devos \& Dunbar, 2012; Noh \& Kaspar, 2003). Work-related consequences of 
perceived discrimination include increased absenteeism and lower productivity (Abbas, Hameed \& Waheed, 2011), job dissatisfaction (Channar, Abbassi \& Ujan, 2011), reduced organisational commitment (Channar et al., 2011; Goldman, Slaughter, Schmit, Wiley \& Brooks, 2008), reduced organisational citizenship behaviour (Ensher, Grant-Vallone \& Donaldson, 2001) and turnover intensions (Goldman et al., 2008). Discrimination in the workplace is also negatively associated with work success and positively related to subtle racism, segregation demands and symptoms of ill health (Jackson et al., 2011). All of these may have severe consequences for the continued existence of the organisation.

\section{Ethnic vitality}

Features of ethnic-minority acculturation have an impact on acculturation outcomes. A group's capacity for information sharing and resource mobilisation may be characterised in terms of its social capital. Social capital refers to the resources or information available through, and embedded within, the network of relationships amongst individuals or amongst social units (Nahapiet \& Ghosphal, 1998). Social capital is based on the relationships that can be developed by exchanging resources, information or support with others. It is different from human capital, which is usually defined as individual ability. In contrast, social capital is more likely to be defined as opportunities of the individual that could be advantageous (Burt, 1997). Since the nature of diversity reflects the relationships amongst individuals, it is rational to examine diversity dynamics from a social capital, as a feature of ethnic vitality, network and support perspective (Chang, 2009).

Ethnic vitality can be regarded as a feature of social capital. In this study, the concept of ethnic vitality refers to ethnic institutions that can support the acculturation process such as the availability of places of worship, shops, recreational opportunities and educational resources (e.g. Adelman, 1988; Malewska-Peyre, 1982). Being psychologically close and sharing more or less the same acculturation experiences, members of the same minority could be very useful in providing social networks for support and expertise about how to deal with the dominant culture. A minority that is vital and supportive acts as both springboard from which minority individuals can deal with the mainstream culture, which is seen in the positive effect on relationships and work success, and as a safety net that provides support to deal with negative acculturation experiences, which is done indirectly via relationships with co-ethnics. There is a controversy, though, as to the role of ethnically vital pockets (Ait Ouarasse, 2004). It is thought that, although ethnic gatherings have the potential to provide a source of help and an opportunity for ventilating feelings, they also can dissociate minority members from engagement in the mainstream context and impede integration (Richardson, 1974).

\section{Social support}

Social support is defined as the general availability of friends and family members that provide psychological and material resources. Much research in sociology (Stack, 2000) and psychology has reported on the beneficial effects of social support. Many psychological studies provide evidence that even the mere perceived availability of social support can have a direct beneficial effect on health and mood (Leskelä, Rytsälä, Komulainen, Melartin, Sokero, Lestelä-Mielonen \& Isometsä, 2006; Nasser \& Overholser, 2005; Nezlek \& Allen, 2006). Research showed that perceived social support may protect individuals against stressful life events (You, Van Orden \& Conner, 2010).

Social support networks have a direct positive effect on immigrants' adjustment (Leong \& Ward, 2011). In addition, the effect of social support has been shown to depend on the stress level but to be much less beneficial to well-being in the absence of stress (Komproe, Rijken, Ros, Winnubst \& Hart, 1997). Social support may enhance the well-being especially when individuals perceive much discrimination. Experiences of discrimination in an acculturation context are exacerbated when support networks are limited or lacking (Finch \& Vega, 2003; Jasinskaja-Lahti \& Liebkind, 2001; Noh \& Kaspar, 2003). Relationships with hosts showed positive links with mainstream integration, mainstream tolerance, perceived minority vitality and school and work success (Ait Ouarasse \& Van de Vijver, 2004). Little is known about the role of ethnic vitality and social support in the acculturation process in the South African workplace.

\section{Intervening factors}

The study of mediating variables has become prominent in psychological theory and research in the last few decades. A mediating variable transmits the effect of an independent variable to a dependent variable (MacKinnon, Fairchild \& Fritz, 2007). One of the primary reasons for the popularity of mediating variables in psychology is the historical authority of the stimulus - organism - response model (Hebb, 1966). In this model, mediating mechanisms in the organism translate how a stimulus leads to a response. Various aspects were treated as mediators in acculturation studies such as acculturation strategies (Jackson \& Van de Vijver, in press). Another reason for the popularity of mediation is the development of statistical theory and the availability of software to deal with mediation models. The interest in this study was in the mediating effect of approach and avoidance coping in the relationship between positive or facilitating contextual factors and discrimination and subjective work success and ill-health symptoms. Coping has been studied as a variable that mediates the relationship between context variables and acculturation outcomes.

\section{Coping}

Understanding how individuals cope with interpersonal problems is of great importance, given that all relationships at some point in time involve problems or tensions that can be stressful to an individual (Carpenter \& Scott, 1992). Negative social interactions and interpersonal stressors (social strain) are negatively associated with health, life satisfaction and positive mood whereas they are positively associated with 
health problems and negative mood (Walen \& Lachman, 2000). Coping refers to 'cognitive and behavioral efforts to master, reduce, or tolerate the internal and/or external demands that are created by the stressful transaction' (Folkman, 1984, p.843). Before actually coping with a situation, it has to be cognitively evaluated as potentially stressful. This appraisal goes through two cognitive mechanisms, which are primary and secondary appraisals. Primary appraisal is an assessment of what is at stake. What is at stake categorise the situation as being a threat, a challenge or a loss (Berjot \& Gillet, 2011). Although negatively correlated (Berjot \& Girault-Lidvan, 2009), threat and challenge appraisals can occur simultaneously. Secondary appraisal is an assessment of coping resources and indicates confidence in one's ability to cope with the situation. Resources can be the following: physical, including health and energy; social, including the social support one can get from family, friends and a social network; psychological including beliefs, self-esteem, perceived control and morale; material, including finances and tools (Berjot \& Gillet, 2011). Three main coping strategies are used to deal with stress, namely emotion-focused, problem-focused (Compas, Connor-Smith, Saltzman, Thomsen \& Wadsworth, 2001) and avoidance-orientated strategies (Endler \& Parker, 1990).

The use of transactional models of stress represents real progress in that it permits better explanations of the variety of responses when encountering discrimination and prejudice as well as the effect of discrimination and prejudice on self-esteem and other adjustment related variables (Major, McCoy, Kaiser \& Quinton, 2003). It also highlights the fact that people are not passive when confronted with discrimination and that individual and situational factors interact to create a specific appraisal of the situation and stimulate specific coping strategies. However, studies that tried to test or directly apply transactional models of stress often failed to show adequate results (Berjot \& Gillet, 2011). Barnes and Lightsey Jr. (2005) asked college students to indicate a measure of perceived racism, coping and perceived stress, and they found that, when people perceive discrimination, it is stressful. However, the perception of discrimination did not predict coping, and coping did not moderate the effect of discrimination on stress. Other authors tried to test the transactional model of stress for the study of stereotype threat. The results of Berjot, Girault-Lidvan, Scharnitsky and Gillet (2010) revealed that stereotype threat enhances the use of emotion-focused strategies and decreases the use of problem-focused strategies. Still, the transactional model of stress failed to explain the whole process by which performance decreases for threatened individuals (Berjot \& Gillet, 2011). It can be concluded that the role of coping as mediating between antecedent variables and outcomes has a better theoretical than empirical underpinning in the context of acculturation.

\section{Acculturation outcomes}

Berry (1992) proposed a definition of adjustment as a state whereby change occurs in the individual in a direction of increased fit and reduced conflict between the environmental demands and the individual attitudinal and behavioural inclinations. Successful adjustment, therefore, can be characterised as a state of equilibrium whereby an individual maintains a balanced psychological state which results in effective functioning (Torbiorn, 1982). Two facets of adjustment are relevant for the present study: psychological adjustment (physical and psychological ill-health symptoms) and socio-cultural adjustment (subjective experiences of work success). Psychological and socio-cultural adaptation is positively related (Berry, 2003; Ward \& Kenndy, 1999), and the strength of the association is related to the cultural distance and the degree of integration of cross-cultural travellers in the social milieu. A larger cultural distance will be accompanied by a weaker association between psychological and socio-cultural adaptation (Ward \& RanaDeuba, 1999). Berry, Phinney, Sam and Vedder (2006) found that being involved in both cultures (labelled integration) was associated with more psychological and socio-cultural adjustment whilst being involved in neither culture, or being confused about one's situation (diffuse), undermines both forms of adaptation. Belonging to the ethnic profile is associated with poorer socio-cultural adaptation whilst belonging to the national profile is associated with somewhat poorer psychological and socio-cultural adaptation.

\section{The dual-process model of diversity outcomes}

It is argued that there are two, fairly independent, processes that influence diversity outcomes, including well-being at work, namely a negative effort-driven process, also referred to as the health-erosion pathway (Idris, Dollard \& Winefield, 2011). In this pathway, discrimination or other integrationthwarting conditions lead to poor psychological adjustment (physical and psychological ill-health symptoms). In addition, there is a positive motivation-driven process where the presence and experience of positive conditions or acculturation resources lead to better socio-cultural adjustments (increased experiences of subjective work success).

In their dual-process model for acculturation outcomes, Jackson and Van de Vijver (in press) propose that, in the negative stream, acculturation demands or inhibiting intergroup features such as discrimination are related to a (passive) avoidance coping style which mediates the relationship between discrimination and ill-health. Similarly, in the positive stream, acculturation resources or facilitating intergroup features such as a multicultural climate, tolerance of mainstreamers, ethnic vitality and social support are related to an (active) approach coping style which mediates the relationship between positive acculturation conditions and subjective experiences of work success.

In the dual-process model, the positive and negative streams operate in a relatively independent manner. The negative stream is particularly salient for creating conditions for ill-health whilst the positive stream is salient for creating conditions for positive outcomes regarding work. The negative stream deals with the prerequisites of positive 
outcomes. This argument draws on positive psychology where health is seen as not just the absence of disease but also the presence of positive aspects such as well-being. Analogously, in the model, an organisation can only be successful in dealing with diversity if scores on instruments in the negative stream are low and scores in the positive stream are high. The absence of negative factors, such as discrimination, is a prerequisite for positive outcomes regarding work. Such outcomes also require the presence of factors that are conducive for diversity such as respect for all ethnicities in an organisation.

The underlying idea is that positive and negative streams constitute the major lines of causation and that relationships within a stream are much stronger than relationships across streams. 'Crossover relationships' in the model (i.e. associations between the positive and negative stream) are much weaker than the relationships within each of the streams, and there are no direct crossover relationships between positive antecedents and negative mediators and between negative antecedents and positive mediators. Similarly, there should be no direct relationship between a negative antecedent or mediator and a positive outcome. Crossover relationships can only occur within a single layer; for example, positive and negative antecedents may be correlated. Based on the above-mentioned, the following hypotheses are tested in the current study:

- Hypothesis 1: perceived positive and facilitating acculturation conditions and approach coping are positively related to subjective experiences of work success and constitute a positive or motivational stream.

- Hypothesis 2: discrimination, avoidance coping and illhealth symptoms are positively related and constitute a negative or restraining stream or health-erosion pathway.

- Hypothesis 3: approach coping mediates the relationship between positive acculturation conditions and subjective experience of work success.

- Hypothesis 4: avoidance coping mediates the relationship between discrimination and ill-health symptoms.

\section{Contextualising the study}

The dual-process model of diversity outcomes was tested in SAPS. For this study, it was assumed that SAPS, being a multicultural public organisation in a multicultural country, provides a good context for testing diversity and its outcomes. South Africa has a long history of discrimination but, in short, when the Nationalist Party came to power in 1948, the government set about drawing up diabolic laws that would further entrench and extend racial discrimination and segregation (Finchilescu \& Tredoux, 2010). Post-1994, the adoption of the New Constitution (RSA, 1996) nullified all these discriminating laws and introduced a number of laws designed to redress past injustices and discriminatory practices. Examples of such post-apartheid laws are the Labour Relations Act (RSA, 1995), the Employment Equity Act (RSA, 1998) and the widespread use of Broad Based Black Economic Empowerment and Affirmative Action in especially the public sector. One would therefore expect the current workplace to be less discriminatory and characterised by a multicultural climate in especially institutions of the state. However, recent events seem to suggest otherwise. The upsurge of Labour Court cases involving discrimination, as a result of affirmative action, against White people (countrywide), Coloured people (Cape Town) and Indian people (Kwazulu-Natal) concerning promotions in state departments could be explained by the experiences of relative deprivation by these ethnic groups. Relative deprivation is a perception that others are getting more than their fair share of the economic pie (Dambrun, Taylor, McDonald, Crush \& Méot, 2006). So, it appears that, even if discrimination has become much less rampant, it is still a problem in modern South Africa and now involves more ethnic groups than before.

\section{Method \\ Research approach}

A cross-sectional design, utilising surveys, was used to achieve the research objectives. The study was initiated after discussions with the Strategic Management Services of the SAPS in Pretoria.

\section{Research method}

\section{Participants and sampling}

The participants used in the research were conveniently sampled from all volunteers and full-time members of the South African Police Service based in the Pretoria area. In total, 158 fully completed questionnaires were received from the 200 that were distributed, resulting in a $79 \%$ response rate. The characteristics of the sample are displayed in Table 1.

TABLE 1: Sample characteristics.

\begin{tabular}{|c|c|c|}
\hline Characteristics & Category & $\%$ \\
\hline Gender & $\begin{array}{l}\text { Male } \\
\text { Female }\end{array}$ & $\begin{array}{l}57.5 \\
42.5\end{array}$ \\
\hline Age & $\begin{array}{l}18-25 \\
26-35 \\
36-45 \\
46-55 \\
56-60\end{array}$ & $\begin{array}{l}9.2 \\
45.4 \\
38.5 \\
6.2 \\
0.8\end{array}$ \\
\hline Language & $\begin{array}{l}\text { Afrikaans } \\
\text { English } \\
\text { Ndebele } \\
\text { North Sotho } \\
\text { South Sotho } \\
\text { Swazi } \\
\text { Tshivenda } \\
\text { Tswana } \\
\text { Xhosa } \\
\text { Xitsonga } \\
\text { Zulu }\end{array}$ & $\begin{array}{l}23.0 \\
9.9 \\
4.6 \\
17.1 \\
5.3 \\
1.3 \\
2.6 \\
15.1 \\
4.6 \\
6.6 \\
9.9\end{array}$ \\
\hline Qualifications & $\begin{array}{l}\text { Matric } \\
\text { Certificate } \\
\text { Diploma } \\
\text { Degree } \\
\text { Post degree }\end{array}$ & $\begin{array}{l}24.1 \\
9.5 \\
22.6 \\
25.5 \\
18.2\end{array}$ \\
\hline Unit & $\begin{array}{l}\text { Operational } \\
\text { Support }\end{array}$ & $\begin{array}{l}49.3 \\
50.7\end{array}$ \\
\hline Rank & $\begin{array}{l}\text { Admin Clerks } \\
\text { Constable } \\
\text { Sergeant } \\
\text { Inspector } \\
\text { Captain } \\
\text { Superintendent } \\
\text { Senior superintendent } \\
\text { Director }\end{array}$ & $\begin{array}{l}16.4 \\
11.8 \\
6.6 \\
21.7 \\
26.3 \\
12.5 \\
3.3 \\
1.3\end{array}$ \\
\hline Years of experience & $\begin{array}{l}0-5 \\
6-10 \\
11-20 \\
\text { More than } 20\end{array}$ & $\begin{array}{l}37.4 \\
8.4 \\
41.3 \\
11.9\end{array}$ \\
\hline
\end{tabular}

Note: Not all categories add up to $100 \%$ due to missing data 
According to Table 1, the majority of participants were males (57.5\%) from support services $(50.7 \%)$ who had an education level equivalent to a degree $(25.5 \%)$. Most of the participants were between the ages of 36 and $45(93.1 \%)$ and had between 11 and $20(87.7 \%)$ years of experience. The largest language group was Afrikaans (23.0\%) and the modal rank was captain $(26.0 \%)$.

\section{Measuring instruments}

Some instruments with well-established psychometric properties used in other cultural contexts were adapted (Ait Ouarasse \& Van de Vijver, 2004). Adaptations involved replacing Dutch and Moroccan with South African and own ethnic group, respectively. All acculturation scales follow a five-point Likert format ranging from strongly agree (5) to strongly disagree (1), and some item scores were reversed before the analyses so that higher scores reflect more endorsement of the underlying attitude.

\section{Mainstream domain instruments:}

- Multicultural norms (developed for the study by the researchers involved). This is a 13-item measure of the participants' multiculturalism attitudes and the prevalence of multicultural values within organisation. The scale contains items like 'I think that most of my co-workers do not recognise that we are a workforce that consists of groups from different cultural groups' (reverse scored).

- Tolerance by the mainstream (adaptation from Ait Ouarasse \& Van de Vijver, 2004). This is an eight-item measure of the extent to which participants think that mainstream members take an open stance toward the ethnic minority in the South African workplace. Tolerance is the desire on the part of the mainstream to see the minority members actively involved in public life without necessarily dropping their original culture. The scale contains items like 'I think that most of my co-workers from other cultures are most welcoming people'.

- Multicultural practices. This new instrument is a 13item measure of the participants' actual multicultural behaviour and support for multicultural practices within the organisation. The scale contains items like 'My coworkers generally show respect other cultures in our organisation'.

- Perceived discrimination (Ait Ouarasse \& Van de Vijver, 2004). The scale is an 11-item measure of the extent to which participants think that pressure is exerted on minorities to comply fully with the regulations and the general atmosphere regardless of whether these regulations encroach on minority sensitivities. The scale contains items like 'I experience discrimination in the dormitory'.

- Perceived ethnic vitality (adaptation from Ait Ouarasse, 2004). This is a six-item measure of the extent to which participants think their own ethnic group has succeeded in creating an infrastructure for the provision of services of a secular and recreational nature. The scale contains items like 'Social functions at work make provision for my cultural customs and habits (e.g. music, food, etc.)'.

- Co-ethnic social support at work (adaptation from Ait Ouarasse \& Van de Vijver, 2004). This is a six-item measure of the amount of perceived support, assistance and protection available from c-ethnic members in the workplace. The scale contains items like'I can count on the help of my cultural group members in our organisation'.

\section{Individual intervening instrument:}

- Coping skills were measured with the 33-item coping strategy indicator (Amirkhan 1990). The scale measures three types of coping strategies: problem solving, seeking social support and avoidance. Participants were asked to imagine themselves in a period when they experienced a serious problem and to indicate how they dealt with it (indicating agreement or disagreement with possible reactions).

\section{Psychological and socio-cultural acculturation outcomes:}

- Health: This is an adapted version of the 18 physical health symptoms of the PSI of Spector and Jex (1998), complemented with a list of nine common psychological complaints based on a slightly modified version of the World Health Organization's Cross-National Survey of Psychological and Somatic Symptoms (World Health Organization, 1988). The scale employs a frequency format that ranges from never (1) to every day (5). The self-report measure asks respondents to indicate whether or not, in the past three months, they have suffered from any of the mentioned symptoms. Some examples of symptoms included in the scale are headaches, backache, fatigue, eyestrain and trouble sleeping, concentrating and constant anxiety or panic attacks.

- Work success (Ait Ouarasse \& Van de Vijver, 2004). This is a 14-item measure of participants' self-reported success at work. All of the items are positively phrased. It contains items pertaining to task completion, punctuality, status, recognition at work, relationships with supervisors and relationships with fellow workers. The scale contains items like 'I do my work exactly as instructed by my supervisor' and 'I have a good reputation amongst my co-workers'.

A biographical questionnaire is included in order to be able to describe the population. It includes basic biographical questions like age, sex, first language, and experience.

\section{Research procedure}

The Strategic Management Services of the SAPS in Pretoria gave permission to carry out the project. English questionnaires with the letter of permission from the Strategic Management Services of the SAPS and a letter emphasising the voluntary and anonyms nature of the study were distributed to police units or departments in Gauteng at various SAPS offices in the Pretoria area.

\section{Statistical analysis}

The data were captured in an Excel spread sheet, checked for mistakes and statistically analysed with the SPSS-program 
(SPSS Inc., 2010). The participants used in the research were all volunteers and full-time members of the SAPS, based in the Pretoria area. Table 1 presents some of the characteristics of the participants $(n=158)$.

\section{Results}

The results section has two parts. The first section presents descriptive statistics of the measures and their relationships whilst the second part addresses the proposed model and mediating effects of the intervening variables.

\section{Factor analysis, descriptive statistics and relationships between measures}

Exploratory factorial analyses were conducted on the scales to examine their dimensionality. Items with factor loadings higher than 0.3 were considered sufficient descriptors of the latent variable. Scree plots suggested that unifactorial solutions were obtained for acculturation context and outcomes scales: Multicultural Norms (41.8\% explained by first factor), Multicultural Practises (42.7\%), Tolerance (47.7\%), Ethnic Vitality at Work (35.6\%), Ethnic Social Support at Work (44.7\%), Discrimination at Work (43.5\%), Work Success Scale (38.6\%) and Ill-Health (86.83\%). In line with the literature, three salient factors for the Coping Strategy Indicator of Amirkhan (1990) were found, which were labelled Approach Coping, Avoidance Coping and Seeking Social Support (see Table 2). The three factors explained $44.9 \%$ of the variance. The meansscale scores of multicultural norms, multicultural practices, tolerance, ethnic vitality and ethnic social support were merged into a single observed factor and in an exploratory factor analysis a single factor was extracted, which was labelled positive acculturation conditions (that explained 39.1\% of the variance of the factor). The descriptive statistics and internal consistency of the measuring instruments used in this study are reported in Table 3.

Inspection of Table 2 shows that acceptable Cronbach alpha coefficients $(>0.70)$ were obtained for all the scales used except for the positive-conditions scale. Cronbach's alpha values below 0.70 according to Kline as quoted by Field (2009) can realistically be expected when working with psychological constructs because of the diversity of the constructs comprising positive conditions. Moreover, in order not to overload the path model with observed variables, it was decided to use the positive conditions as a single variable. The correlation coefficients between the different measures used in this study are also presented in Table 3. All correlations showed the expected signs. Positive conditions were positively significantly related to one another and with work success whilst they were also very weakly negatively associated with ill-health. At the same time, discrimination was negatively related to positive conditions and work success and positively significantly associated with ill-health symptoms.

\section{A test of the dual-process model}

Structural-equation modelling (SEM) was performed using AMOS 18 (Arbuckle, 2010) to test the dual-process model.

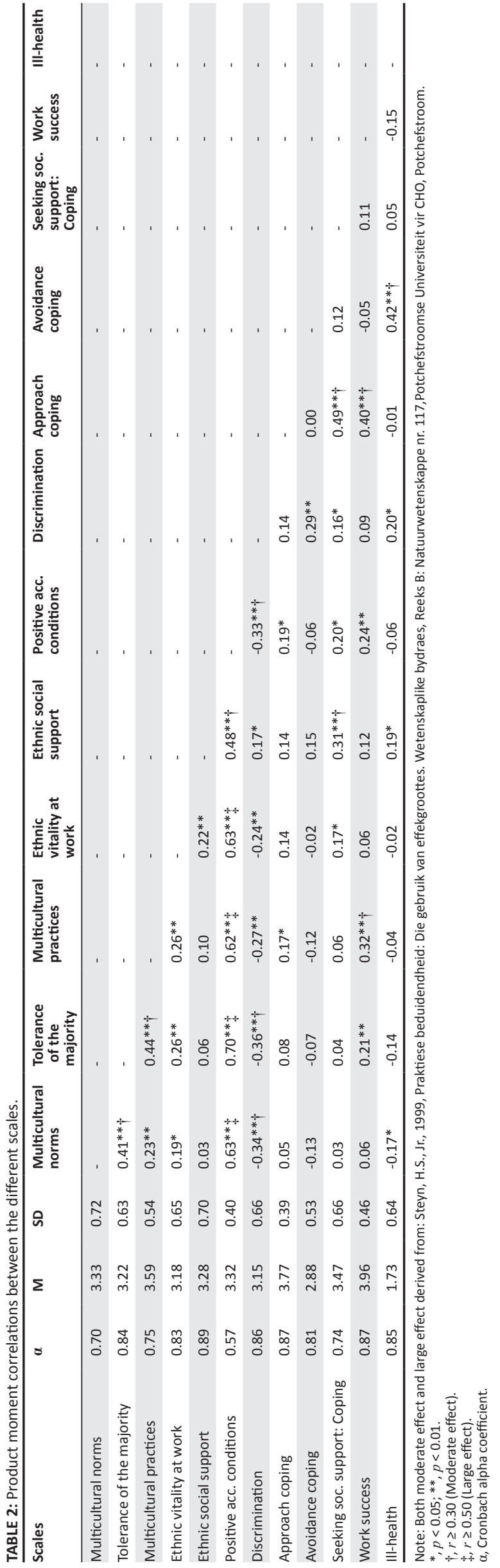


TABLE 3: Mediation effects of integration demands in the workplace (standardised effects).

\begin{tabular}{|c|c|c|c|c|c|c|}
\hline \multirow[t]{2}{*}{ Predictor } & \multicolumn{3}{|c|}{ Work success } & \multicolumn{3}{|c|}{ Ill-health symptoms } \\
\hline & Direct & Indirect & Total & Direct & Indirect & Total \\
\hline Positive conditions & $0.16^{*}$ & $0.07^{*}$ & $0.23^{*}$ & 0.00 & 0.00 & 0.00 \\
\hline Approach coping & $0.37 *$ & 0.00 & $0.37 *$ & 0.00 & 0.00 & 0.00 \\
\hline Discrimination & 0.00 & -0.03 & -0.03 & 0.08 & $0.12 *$ & $0.20 *$ \\
\hline Avoidance coping & 0.00 & -0.05 & -0.05 & $0.42 *$ & 0.00 & $0.42 *$ \\
\hline
\end{tabular}

Note: Effects in bold refer to effects that are part of the theoretical model and are expected to be positive whereas other cells are expected to be zero. $*, p<0.05$

A model was postulated in which a split was made between positive and negative antecedent conditions, two coping strategies (active coping as positive coping strategy and avoidance coping as negative coping strategy) and two types of outcomes (perceived work success as positive outcome and ill-health as negative outcome). More specifically, five positive acculturation antecedent conditions (the combination of the average scale scores of multicultural norms, mainstream tolerance, multicultural practices, ethnic vitality, social support) impact on subjective work success (sociocultural adjustment), both directly and indirectly through active coping. Similarly, discrimination impacts on ill-health (psychological adjustment), both directly and indirectly through avoidance coping. The antecedent conditions were allowed to co-vary; no direct relations were allowed between the coping strategies. Finally, it was predicted that ill-health would predict work success (in line with a previous study amongst miners in South Africa) (Jackson \& van de Vijver, in press). The argument behind the latter association is that the absence of ill-health is a prerequisite for work success. The model was tested by fitting the empirical data to the hypothetical model by using various indices to assess the goodness of fit of the model. The results of the structural equation model are presented in Figure 1.

A very good fit for the proposed hypothetical model was obtained (see Figure 1): $\chi^{2}(7, N=158)=11.60, p=0.12$; $\chi^{2} / d f=1.66$ (recommended $\leq 3.00$ ), adjusted goodness of fit index $($ AGFI $)=0.93$ (recommended $\geq 0.90)$, the Tucker Lewis index $(\mathrm{TLI})=0.90$ (recommended $\geq 0.90)$, the comparative fit index $(\mathrm{CFI})=0.96$ (recommended $\geq 0.90$ ) and the root mean square error of approximation (RMSEA) was 0.07 (recommended $\leq 0.05$ ). Positive mainstream and ethnic acculturation conditions are associated with approach coping as the intervening variable, which in turn is related to subjective experiences of work success. Positive conditions (i.e. more positive mainstream multicultural norms, mainstream tolerance and multicultural practices, ethnic vitality and social support) are associated with an approach coping style at work and higher subjective experiences of work success. More discrimination and more physical and psychological ill-health symptoms were associated with an avoidance coping style. Finally, the model shows that illhealth was negatively associated with subjective work success.

The standardised coefficients of Figure 1 also indicate that the path from discrimination via avoidance coping to illhealth had a fair standardised regression weight (0.39), as did the path from positive conditions via approach coping to subjective work success (0.37). The proportion of variance

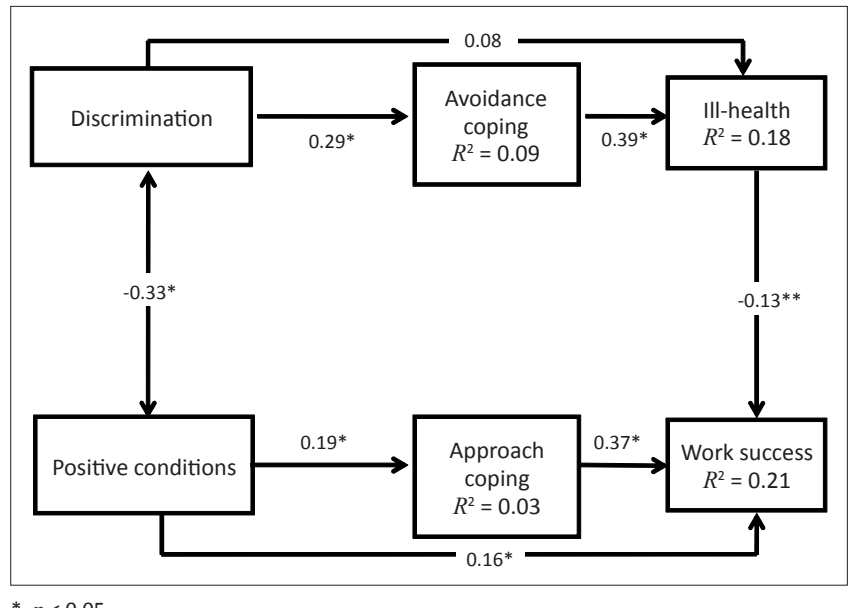

$*, p<0.05$

$*^{*}, p<0.10$

FIGURE 1: The results of the structural equation model analysis of the dualprocess model.

explained in subjective work success $(0.21)$ was comparable to that of ill-health (0.18). The direct path from discrimination to ill-health was statistically non-significant whilst the path from ill-health to work success was negative and bordered on significance $(p<0.06)$.

\section{Mediating effects of approach coping}

The hypothesised model is a mediation model in which positive antecedent conditions and discrimination influence approach and avoidance coping styles, which in turn impact on work success and ill-health symptoms, respectively. A closer examination of the direct and indirect effects to evaluate their relative size was performed. There is a significant volume of literature on the testing of mediation effects (Baron \& Kenny, 1986; Holmbeck, 1997; Hoyle \& Kenny, 1999; Judd \& Kenny, 1981; Kline, 1998; Preacher \& Hayes, 2004). It has been found that the method proposed by Baron and Kenny (1986) can have a low statistical power and that joint significance tests involving the product of coefficients showed greater statistical power than other procedures, including the Baron and Kenny approach (MacKinnon, Lockwood, Hoffman, West \& Sheets, 2002). Therefore, in keeping with the structural equation framework to compute the significance of mediation effects, the bootstrap procedure as implemented in the AMOS program was used. The results of the mediation analysis can be found in Table 5 .

An inspection of Table 3 indicates that, in line with observations from Figure 1, positive conditions had total, direct and indirect effects on subjective experience on work 
success but not on ill-health symptoms. In addition, the significance of both the direct and indirect effects indicates that the link with subjective work success is partially mediated by approach coping. Positive-antecedent conditions have, therefore, a salient influence on the subjective experience of work success. Direct and indirect effects were all positive and reinforced each other, as expected in the dual-process model. It can be concluded that approach coping partially mediates the path from positive acculturation conditions to socio-cultural adjustment and that multiculturalism, ethnic vitality and social support are important for the experience of subjective work success but not for ill-health symptoms in the SAPS employees of this sample. Discrimination had only significant total and indirect effects on ill-health symptoms. It can therefore also be concluded that avoidance coping fully mediates the relationship between discrimination and ill-health symptoms and that discrimination and avoidance coping matter for ill-health symptoms for members for members in the SAPS of this sample.

\section{Discussion}

The first objective of this study was to test a mediation dualprocess model for diversity (Jackson \& Van de Vijver, in press) amongst members of the South African Police Service in Gauteng. It was hypothesised that perceived positive or facilitating acculturation conditions and approach coping are all strongly positively related to subjective experiences of work success and that discrimination and avoidance coping are related positively to ill-health symptoms but negatively to subjective experiences of work success. Antecedents in the model, called acculturation conditions, refer to contextual conditions with a bearing on the acculturation process such as multiculturalism, tolerance, ethnic vitality and social support. Mediating variables, active and avoidance coping strategies, refer to the way individuals prefer to handle conflict and stressful situations. It was assumed that support for and the experience of acculturationfacilitating conditions (Jackson \& Van de Vijver, in press), when coupled with an approach coping orientation, will positively influence outcomes of the acculturation process such as the perceived subjective experience of work success. However, discrimination, when coupled with an avoidance coping style, positively impacts on ill-health symptoms. An analysis of the correlation matrix, regression weights obtained from the model testing as well as the very good fit obtained revealed relationships and associations between variables in the expected directions. It can be concluded that more mainstream multiculturalism, mainstream tolerance, ethnic vitality and social support coupled with an approachcoping orientation were associated with more subjective experience of work success whereas more discrimination and an avoidance-coping style were associated with more ill-health symptoms. Support was therefore found for the dual-process model. Furthermore, it was found that direct and indirect effects all go in the same direction and tend to reinforce each other. These findings therefore provided support for the acceptance of Hypotheses 1 and Hypotheses 2. These results confirm previous empirical findings (Jackson, Ali \& Burkard, 2006; Jackson \& Van de Vijver, in press) that also supported the dual-process model of diversity. In the previous study, involving miners in the North-West Province, positive correlations were also found between markers of a multiculturalism climate such as relationships with host members, tolerance of mainstreamers, multicultural practices, ethnic vitality at work, ethnic social support and relationship with co-ethnics. The positive link of these diverse city-enhancing conditions with work outcomes is in line with the cross-cultural literature which shows that good socio-cultural adaptation is predicted by cultural knowledge, degree of contact and positive intergroup attitudes (Berry et al., 2002). The findings of the present study concur with the findings obtained in the dual-process model for diversity (Jackson \& Van de Vijver, in press) that argue that the 'crossover relationships' in the model between the positive and negative stream are much weaker than the relationships within each of the streams.

The second objective of the study was to determine the mediating effects of approach and avoidance coping styles in the relationship between positive or facilitating acculturation conditions, discrimination and subjective experience of work success and ill-health, respectively. These findings indicate that positive conditions had total, direct and indirect effects on the subjective experience of work success but not on illhealth symptoms. Positive antecedent conditions therefore have a significant direct and indirect influence on the subjective experience of work success. It can be concluded that approach coping partially mediates the path from positive acculturation conditions to socio-cultural adjustment and that multiculturalism, ethnic vitality and social support are important for the experience of subjective work success whilst avoidance coping only fully mediates the relationship between discrimination and ill-health symptoms in the SAPS sample. These results provide support for the acceptance of Hypothesis 3 and Hypotheses 4 and confirm that an approach-coping style or problem-focused strategies are active problem-solving methods used to resolve the stressful relationship between the self and the environment (Compas et al., 2001). The present findings also concur with the results obtained by Ward and Kennedy (2001) that the most powerful predictor of poor psychological adjustment is an avoidant coping style. It has been argued that avoidant responses may have some utility during primary appraisal by temporarily distancing the individual from an overwhelming stressor (Carver, Scheier \& Weintraub, 1989). However, distancing behaviour cannot be sustained for long periods where forced contact takes place such as in the workplace. This finding is also supported by Chataway and Berry's (1989) findings, who found that detachment is associated with increased psychological distress.

The implications of the present results are that mainstream and ethnic positive or facilitating conditions and discrimination are important for and do influence individual coping styles, which in turn impact on ill-health as well as the experience of work success. In addition, ill-health also impacted negatively on work success experiences amongst the sampled SAPS members. It therefore would make sense for higher- 
ranking officers in the SAPS to sanction discrimination and monitor positive conditions and also reward behaviour associated with positive conditions in order to encourage SAPS members to treat colleagues from different ethnic backgrounds in a fashion that enhances the experiences of positive or facilitating conditions such as multiculturalism and tolerance as well as to provide social support to own ethnic members. Taking measures to curb discrimination is expected to increase the wellness of employees at work, whilst stimulating diversity conditions, can be expected to lead to more positive work-related outcomes. Both positive and negative diversity conditions can be influenced by institutional policies. Thus, diversity training could be considered to be a focus on basic awareness of differences, skills for dealing with differences and cultural competence. Most organisations focus on awareness during the initial training session. This helps participants to understand their own biases and values and to obtain a better understanding of other people's perspective, helping to build empathy and increasing intercultural communication in a diverse group of employees. Skills building should start with managers and senior staff but should ultimately be extended to employees as well. The training should be focused on developing an organisation that is inclusive with regard to ethnicity and where adverse practices like discrimination are clearly sanctioned. This approach is most effective following an initial awareness-training programme (Kay \& Stringer, 2003). It is advised that this training should be experiential in nature, meaning that real organisational incidents should be simulated, or relevant case studies and videos should be utilised as teaching aids to increase the effectiveness of the training (Tan, Morris \& Romero, 2003). In addition, the policies related to diversity issues should be transparent and accessible for all, and the content thereof should be discussed, reviewed and updated so that workshop contents reflect current realities and employees are aware of the institutional agenda vis-à-vis diversity.

Intergroup contact in SAPS creates opportunities for people of different backgrounds to understand and appreciate members of other groups (Leong \& Ward, 2011), has the potential to reduce intergroup prejudices, disconfirms negative stereotypes, enhances knowledge of the out-group and reduces interpersonal anxiety (Pettigrew \& Tropp, 2006; Sakalli \& Ugurlu, 2001; Voci \& Hewstone, 2003; Wagner, Hewstone \& Machleit, 1989). It is regrettable that the South African society is so strongly segregated, which implies that interethnic contact is relatively sparse outside of the work context, even though such contact would foster intergroup relationships in the interpersonal and work sphere.

Experiences in various countries with positive discrimination are not always encouraging. It is relatively common to find resistance against positive discrimination by groups that are no longer favoured. This also constitutes a potential risk for South Africa, as there are indications that feelings of discrimination can now be observed in all ethnic groups.

\section{Limitations}

The limitations of the present study include the sampling procedure (our sample was limited to police officers in Gauteng) as this may influence the possibility of generalisation of the findings to the total study population.

\section{Suggestions for future research}

Future studies could benefit from using a stratified randomsample design, which would ensure sufficient representation of the different groups in the total population. Future studies should also focus on longitudinal designs where inferences in terms of cause and effect could be made.

\section{Conclusion}

A dual-process model of diversity outcomes was tested in which a distinction is made between a positive (workrelated) stream that links positive diversity conditions through active coping to work outcomes and a relatively independent (health-related) stream of negative antecedents, mediating passive coping skills and ill-health related outcomes. The model was tested in a convenience sample $(n=158)$, and respondents were recruited from members of the SAPS in Gauteng. The data supported the model. Conditions that facilitate or impede diversity, such as workplace discrimination, influence individual coping styles, which in turn impact on ill-health and the subjective experiences of work success. It is conducive for a diversity climate to sanction discrimination. A positive diversity climate facilitates well-being and productivity.

\section{Acknowledgements Competing interest}

The authors declare that they have no financial or personal relationships which may have inappropriately influenced them in writing this article.

\section{Authors' contributions}

L.T.B.J. (North-West University and Tilburg University) was responsible for the literature review, statistical analyses, manuscript review and submission. F.V. (Tilburg University and North-West University) was responsible for the review and advice on matters relating to the literature, statistical analyses, and final manuscript and lastly D.M. (North-West University) was responsible for all the data collection, initial literature review and the manuscript preparation.

\section{References}

Abbas, Q., Hameed, A., \& Waheed, A. (2011). Gender discrimination and effect on employment performance/productivity. International Journal of Humanities and Social Science, 1(15), 170.

Adelman, M.B. (1988). Cross-cultural adjustment: A theoretical perspective on social support. International Journal of Intercultural Relations, 12, 183-205. http:// dx.doi.org/10.1016/0147-1767(88)90015-6

Ait Ouarasse, O. (2004). What immigration does to young people: The psychological acculturation of Moroccans in the Netherlands, PhD thesis, Department of Psychology, University of Tilburg, Tilburg, Netherlands. 
Ait Ouarasse, O., \& Van de Vijver, F.J.R. (2004). Structure and function of the perceived acculturation context of young Moroccans in the Netherlands. International Journal of Psychology, 39, 190-204. http://dx.doi.org/10.1080/00207590344000367

Amirkhan, J.L. (1990). A factor analytically derived measure of coping: The coping strategy indicator. Journal of Personality and Social Psychology, 59, 1066-1074. http://dx.doi.org/10.1037//0022-3514.59.5.1066

Antaramian, S.P., Huebner, E.S., Hills, K.J., \& Valois, R.F. (2010). A dual-factor mode of mental health: Toward a more comprehensive understanding of youth functioning. American Journal of Orthopsychiatry, 80, 462-472. http://dx.doi. org/10.1111/j.1939-0025.2010.01049.x

Arbuckle, J.L. (2010). Amos 18. Chicago, IL: Smallwaters.

Arends-Toth, J., \& Van de Vijver, F.J.R. (2000). Multiculturalisme: Spanning tussen ideal en realiteit [Multiculturalism: More and ideal than reality.] Nederlands Tijdschift voor de Psychologie, 55, 159-168.

Arends-Tóth, J.V., \& Van de Vijver, F.J.R. (2006). Issues in conceptualization and assessment of acculturation. In M.H. Bornstein \& L.R. Cote (Eds.), Acculturation and parent-child relationships: Measurement and development (pp. 33-62). Mahwah, NJ: Erlbaum.

Barnes, P.W., \& Lightsey, O.R. Jr. (2005). Perceived racist discrimination, coping, stress and life satisfaction. Journal of Multicultural Counselling and Development, 33, 48-61. http://dx.doi.org/10.1002/j.2161-1912.2005.tb00004.x

Baron, R.M., \& Kenny, D.A. (1986). The moderator-mediator variable distinction in social psychological research: Conceptual, strategic, and statistical considerations. Journal of Personality \& Social Psychology, 51, 1173-1182. http://dx.doi. org/10.1037//0022-3514.51.6.1173

Berjot, S., \& Gillet, N. (2011). Stress and coping with discrimination and stigmatization Frontiers in Psychology, 2, 1-13. Front. Psychol. http://dx.doi.org/10.3389/ fpsyg.2011.00033

Berjot, S., \& Girault-Lidvan, N. (2009). L'échelle d'Evaluation Cognitive Primaire 'Trait' [The 'trait' primary cognitive appraisal scale]. Canadian Journal of Behavioral Sciences, 58, 418-434.

Berjot, S., Girault-Lidvan, N., Scharnitsky, P., \& Gillet, N. (2010). Comment les étudiants francais d'origine maghré-bine evaluent et font face à la menace de steréotype. Application du modèle transactionnel du stress à la menace de stéréotype [How students from North African origins appraise and cope with stereotype threat: application of the transactional model of stress to the study of stereotyp threat]. L'Année Psychologique, 110, 427-451. http://dx.doi.org/10.4074/ S0003503310003064

Berry, J.W. (1992). Acculturation and adaptation in a new society. International Migration, 30, 69-86. http://dx.doi.org/10.1111/j.1468-2435.1992.tb00776.x

Berry, J.W. (1997). Immigration, acculturations, and adaptations. Applied Psychology, An International Review, 46, 5-34. http://dx.doi.org/10.1111/j.1464-0597.1997. tb01087.x

Berry, J.W. (2003). Conceptual approaches to acculturation. In K.M. CChun, P.B. Organista \& G. Martin (Eds.). Acculturation: Advances in theory, measurement Organista \& G. Martin (Eds.). Acculturation: Advances in theory, measurement,
and applied research (pp. 17-39). Washington DC: American Psychological and applied

Berry, J.W., \& Kalin, R. (1995). Multiculturalism and ethnic attitudes in Canada: An overview of the 1991 National Survey. Canadian Journal of behavioural Sciences, 27, 301-320. http://dx.doi.org/10.1037/0008-400X.27.3.301

Berry, J.W., Phinney, J.S., Sam, D.L., \& Vedder, P. (Eds.), (2006). Immigrant youth in cultural transition: Acculturation, identity and adaptation across national contexts. Mahwah, NJ: Lawrence Erlbaum Associates.

Bourhis, R.Y., Moise, L.C., Perreault, S., \& Senecal, S. (1997). Toward an Integrative Acculturation Model: A social psychology approach. International Journal of Psychology, 32, 369-386. http://dx.doi.org/10.1080/002075997400629

Breugelmans, M.S., \& Van de Vijver, F.J.R. (2004). Antecedents and components of majority attitudes toward multiculturalism in the Netherlands. Applied Psychology: An International Review, 53(3), 400-422. http://dx.doi.org/10.1111/ j.1464-0597.2004.00177.x

Burt, R. S. (1997). The contingent value of social capital. Administrative Science Quarterly, 42, 339-365. http://dx.doi.org/10.2307/2393923

Carpenter, B.N., \& Scott, S.M. (1992). Interpersonal aspects of coping. In B.N. Carpenter (Ed.), Personal coping: Theory, research, and application (pp. 93-110). New York: Praeger.

Carver, C.S., Scheier, M.F., \& Weintraub, J.K. (1989). Assessing coping strategies: A theoretically based approach. Journal of Personality and Social Psychology, 56 , 267-283. http://dx.doi.org/10.1037/0022-3514.56.2.267

Cascio, W.F. (2010). Managing human resources: Productivity, quality of life, profits. 8th edn. Boston, MA: McGraw-Hill Irwin.

Chang, B. (2009). Examining links between diversity and outcomes in work groups: Effects of different levels of social networks The Graduate Faculty of the University of Akron.

Channar, Z.A., Abbassi, Z., \& Ujan, I.A. (2011). Gender discrimination in workforce and its impact on the employees. Pakistan Journal of Commerce \& Social Sciences, 5(1), 177-191.

Chataway, C.J., \& Berry, J.W. (1989). Acculturation experiences, appraisal, coping and adaptation: A comparison of Hong Kong Chinese, French, and English students in Canada. Canadian Journal of Behavioral Science, 21, 295-309. http://dx.doi. org/10.1037/h0079820

Citrin, J., Sears, D.O., Mutse, C., \& Wong, C. (2001). Multiculturalism in American public opinion. British Journal of Political Science, 31, 247-275.

Compas, B.E., Conner-Smith, J.K., Saltzman, H., Thomsen, A.H., \& Wadsworth, M.E. (2001). Coping with stress during childhood and adolescence: Problems, progress and potential in theory and research. Psychological Bulletin, 127(1), 87-127. http://dx.doi.org/10.1037//0033-2909.127.1.87
Dambrun, M., Taylor, D., McDonald, D.A., Crush, J., \& Méot, A. (2006). The relative deprivation-gratification continuum and the attitudes of South Africans towards immigrants: A test of the $V$ curve hypothesis. Journal of Personality and Socia Psychology, 91, 1032-1044. http://dx.doi.org/10.1037/0022-3514.91.6.1032

Demerouti, E., Bakker, A.B., Nachreiner, F., \& Schaufeli, W. (2001). The job demandsresources model of burnout. Journal of Applied Psychology, 86, 499-512. http:// dx.doi.org/10.1037/0021-9010.86.3.499

Eldering, L. (1996). Multiculturalism and multicultural education in an internationa perspective. Anthropology and Education Quarterly, 27(3), 315-330. http:// dx.doi.org/10.1525/aeq.1996.27.3.04x0352n

Endler, N.S., \& Parker, J.D.A. (1990). Multidimensional assessment of coping: A critical evaluation. Journal of Personality and Social Psychology, 58(5), 844-854. http:// dx.doi.org/10.1037//0022-3514.58.5.844

Ensher, E.A., Grant-Vallone, E.J., \& Donaldson, S.I. (2001). Effects of perceived discrimination on job satisfaction, organizational commitment, organizational citizenship behavior, and grievances. Human Resource Development Quarterly, citizenship behavior, and grievances. Human Resource Development Quarterly,
12(1), 53-72. http://dx.doi.org/10.1002/1532-1096(200101/02)12:1<53::AID12(1), 53-72. http:/
HRDQ5>3.0.CO;2-G

Ewart, C., Taylor, C.B., Kraemer, H.C., \& Agras, W.S. (1991). High blood pressure and marital discord: Not being nasty matters more than being nice. Health Psychology, marital discord: Not being nasty matters more than being nice.
10, 155-163. http://dx.doi.org/10.1037/0278-6133.10.3.155

Field, A. (2009). Discovering statistics using SPSS. 3rd edn. Sage Publications, London.

Finch, B.K., \& Vega, W.A. (2003). Acculturation stress, social support, and self-rated health among Latinos in California. Journal of Immigrant Health, 5(3), 109-117. $\mathrm{http}: / / \mathrm{dx}$.doi.org/10.1023/A:1023987717921

Finchilescu, G., \& Tredoux, C. (2010), The changing landscape of intergroup relations in South Africa, Journal of Social Issues, 66(2), 223-236. doi.org/10.1111/j.15404560.2010.01642.x

Folkman, S. (1984). Personal control and stress and coping processes: A theoretical analysis. Journal of Personality and Social Psychology, 46, 839-852. http://dx.doi. org/10.1037/0022-3514.46.4.839

Folkman, S., \& Lazarus, R.S. (1988). Ways of coping questionnaire. Palo Alto, CA: Mind Garden.

Gee, G.C., Ro, A., Shariff-Marco, S., \& Chae, D. (2009). Racial discrimination and health among Asian Americans: Evidence, assessment, and directions for future research. Epidemiologic Reviews, 31(1), 130-151. http://dx.doi.org/10.1093/ epirev/mxp009

Goldman, B.M., Slaughter, J.E., Schmit, M.J., Wiley, J.W., \& Brooks, S.M. (2008). Perceptions of Discrimination: A multiple needs model perspective. Journal of Management, 34(5), 952-977. http://dx.doi.org/10.1177/0149206308318613

Hakanen, J., Bakker, A.B., \& Schaufeli, W.B. (2006). Burnout and work engagement among teachers. Journal of School Psychology, 43, 495-513. http://dx.doi. org/10.1016/j.jsp.2005.11.001

Hakanen, J.J., Schaufeli, W.B., \& Ahola, K. (2008). The Job Demands-Resources model: A three-year cross-lagged study of burnout, depression, commitment, and work engagement. Work \& Stress, 22, 224-241. http://dx.doi. and Work engagement. Work
org $/ 10.1080 / 02678370802379432$

Hebb, D.O. (1966). A textbook of psychology (2 ${ }^{\text {nd }}$ Edition). Philadelphia, PA: Saunders.

Herbert, T.B., \& Cohen, S. (1993). Stress and immunity in humans: A meta-analytic review. Psychosomatic Medicine, 55, 364-379. http://dx.doi.org/10.1037//0033 2909.113.3.472

Herman, D. (2000). The counter side of affirmative action. Pretoria: Jotha Publishers

Holmbeck, G.N. (1997). Toward terminological, conceptual, and statistical clarity in the study of mediators and moderators: Examples from the child-clinical and pediatric psychology literatures. Journal of Consulting \& Clinical Psychology, 65 599-610. http://dx.doi.org/10.1037//0022-006X.65.4.599

Hoyle, R.H., \& Kenny, D.A. (1999). Sample size, reliability, and tests of statistical mediation. In R. Hoyle (Ed.), Statistical strategies for small sample research (pp. 195-222). Thousand Oaks, CA: Sage.

Huynh, Q.L., Devos, T., \& Dunbar, C.M. (2012). The psychological costs of painless but recurring experiences of racial discrimination. Cultural Diversity and Ethnic Diversity Psychology, 18, 26-34. http://dx.doi.org/10.1037/a0026601

Idris, M.A., Dollard, M.F., \& Winefield, A.H. (2011). Integrating psychosocial safety climate in the JD-R model: A study amongst Malaysian workers. South African Journal of Industrial Psychology, 37, 851-862. http://dx.doi.org/10.4102/sajip. v37i2.851

Jackson, L.T.B., \& Van de Vijver, A.J.R. (in press). Diversity in the workplace: A dual process model.

Jackson, L.T.B., Ali, S. \& Burkard, A. (2006, April 6). Diversity management: Acculturation context variables as predictors of work-related outcomes in a mine. Paper presented at the 1st South African Positive Psychology Conference, Potchefstroom, South Africa.

Jackson, L.T.B., Rothmann, S., \& Van de Vijver, F.J.R. (2006). A model of work-related well-being for educators in South Africa. Stress and Health, 22, 267-274. http:// dx.doi.org/10.1002/smi.1098

Jackson, L.T.B., Van de Vijver, A.J.R, \& Ali, S. (2012). Positive acculturation conditions and well-being in a mine in the North-West province. South African Journal of Industrial Psychology, 38(1), 38-48.

Jackson, L.T.B., Van de Vijver, A.J.R., \& Burkard, A. (2011). Adverse acculturation conditions and well-being of mine employees in the North West Province. Journa of Psychology in Africa, 21(3), 385-396.

Jasinskaja-Lahti, I., \& Liebkind, K., 2001, 'Perceived discrimination and psychological adjustment of Russian speaking immigrant adolescents in Finland. International Journal of Psychology, 36(3), 174-185. http://dx.doi. org/10.1080/00207590042000074 
Judd, C.M., \& Kenny, D.A. (1981). Process analysis: Estimating mediation in treatment evaluations. Evaluation Review, 5, 602-619. http://dx.doi. treatment evaluations. Evaluation

Kay, R.Y., \& Stringer, D.M. (2003). Designing a diversity training programme that suits your organization. In M.J. Davids \& S.L. Fielden (Eds.). Individual diversity and psychology in organizations (pp. 239-252), John Wiley \& Sons: Chichester: England.

Khoza, R. (2002) 'Dancing to our own drum', People Dynamics, 20(5), 20-3.

Kline, R.B. (1998). Principles and practice of structural equation modeling. New York: Guilford.

Komproe, I.H., Rijken, M., Ros, W.J.G.,Winnubst, J.A.M., \& Hart, H. (1997). Available support and received support: Different effects under stressful circumstances. Journal of Social and Personal Relationships, 14(1), 59-77. http://dx.doi. org/10.1177/0265407597141003

Leong, C.H., \& Ward, C. (2011). Intergroup perceptions and attitudes toward immigrants in a culturally plural society. Applied Psychology: An International
Review, 60(1), 46-65. http://dx.doi.org/10.1111/j.1464-0597.2010.00426.x

Leskelä, U., Rytsälä, H., Komulainen, E., Melartin, T., Sokero, P., Lestelä-Mielonen, P. \& Isometsä, E. (2006). The influence of adversity and perceived social support on the outcome of major depressive disorder in subjects with different levels on the outcome of major depressive disorder in subjects with different levels
of depressive symptoms. Psychological Medicine, 36, 779. doi.org/10.1017/ of depressive symptor

MacKinnon, D.P., Lockwood, C.M., Hoffman, J.M., West, S.G., \& Sheets, V. (2002). A comparison of methods to test mediation and other intervening variable effects. Psychological Methods, 7, 83-104. http://dx.doi.org/10.1037//1082-989X.7.1.83

MacKinnon, D.P., Fairchild, A.J., \& Fritz, M.S. (2007). Mediation analysis. Annual Review of Psychology, 58, 593-614. http://dx.doi.org/10.1146/annurev. psych.58.110405.085542

Major, B., McCoy, S.K., Kaiser, C.R., \& Quinton, W.J. (2003). 'Prejudice and self-esteem: A transactional model,' In W. Strobe \& M. Hewstone (Eds.), European Review of Social Psychology, Vol. 14, (pp. 77-104). London: Psychology Press,

Malewska-Peyre, H. (1982). L' experience du racisme et de la xenophobie chez jeunes immigres [The experience of racism and xenophobia among young immigrants]. In $\mathrm{H}$. Malewska-Peyre (Ed.), Crise d'identite et deviance chez jeunes immigres [Identity crisis and deviance among young immigrants] (pp. 53-73). Paris: La Documentation Francaise.

Martinussen, M., Richardsen, A.M., \& Burke, R.J. (2007). Job demands, job resources, and burnout among police officers, Journal of Criminal Justice, 35, 239-249. http://dx.doi.org/10.1016/j.jcrimjus.2007.03.001

Munusamy, V.P. (2009). Decoding the meaning of multiculturalism: An international study of Malaysia, Singapore and Hawaii. PhD dissertation, Department of International Management, University of Hawaii, Hawaii.

Nahapiet, J., \& Ghoshal, S. (1998). Social capital, intellectual capital, and the organizational advantage. Academy of Management Review, 23, 242-266.

Nasser, E.H., \& Overholser, J.C. (2005). Recovery from major depression: The role of support from family, friends, and spiritual beliefs. Acta Psychiatrica Scandinavica, 111, 125-132. http://dx.doi.org/10.1111/j.1600-0447.2004.00423.x

Nezlek, J.B., \& Allen, M.R. (2006). Social support as a moderator of day-to-day relationships between daily negative events and daily psychological well-being. European Journal of Personality, 20, 53-68. http://dx.doi.org/10.1002/per.566

Noh, S., \& Kaspar, V. (2003). Perceived discrimination and depression: Moderating effects of coping acculturation and ethnic support. American Journal of Public Health, 93(2), 232-238. http://dx.doi.org/10.2105/AJPH.93.2.232

Pettigrew, T.F., \& Tropp, L.R. (2006). A meta-analytic test of intergroup contact theory. Journal of Personality and Social Psychology, 90, 751-783. http://dx.doi. org/10.1037/0022-3514.90.5.751

Preacher, K.J., \& Hayes, A.F. (2004). SPSS and SAS procedures for estimating indirect effects in simple mediation models. Behavior Research Methods, Instruments, \& Computers, 3(4), 717-731. http://dx.doi.org/10.3758/BF03206553

Raijman, R., Semyonov, M., \& Schmidt, P. (2003). Do foreigners deserve rights? Determinants of pubic views towards foreigners in Germany and Isreal. European
Sociological Review, 19, 379-392. http://dx.doi.org/10.1093/esr/19.4.379

Redfield, R., Linton, R., \& Herskovits, M.J. (1936). Memorandum on the study of acculturation. American Anthropologist, SD, 973-1002. http://dx.doi. org/10.1525/aa.1936.38.1.02a00330

Republic of South Africa, (1995). The Labour Relations Act, No. 66 of 1995. Pretoria, South Africa: Government Printers.

Republic of South Africa, (1996). Constitution of the Republic of South Africa Act, No. 108 of 1996. Pretoria, South Africa: Government Printers.
Republic of South Africa, (1998). The Employment Equity Act, No. 55 of 1998. Pretoria, South Africa: Government Printers.

Richardson, A. (1974). British immigrants and Australia: A psychosocial inquiry. Canberra: Australian National University Press.

Sakalli, N., \& Ugurlu, O. (2001). Effects of social contact with homosexuals on heterosexual Turkish university students' attitudes toward homosexuality. Journa of Homosexuality, 42(1), 53-62. http://dx.doi.org/10.1300/J082v42n01_03

Schaufeli, W.B., \& Bakker, A.B. (2004). Job demands, job resources, and their relationship with burnout and engagement: A multi-sample study. Journal of Organisational Behaviour, 25, 293-315. http://dx.doi.org/10.1002/job.248

Semyonov, M., Raijman, R., Tov, A.Y., \& Schmidt, P. (2004). Population size, perceived threat, and exclusion: A multiple-indicators analysis of attitudes toward foreigners in Germany. Social Science Research, 33, 681-701. http://dx.doi.org/10.1016/j. ssresearch.2003.11.003

Spector, P.E., \& Jex, S.M. (1998). Development of four self-report measures of job stressors and strain: Interpersonal conflict and work scale, quantitative workload inventory. Journal of Occupational Health Psychology, 3, 356-367. http://dx.doi. org/10.1037//1076-8998.3.4.356

SPSS Inc. (2010). SPSS 18.0 for Windows. Chicago, IL: International Business Machines (IBM)

Stack, S. (2000). Suicide: A 15-year review of the sociological literature part II: Modernization and social integration perspectives. Suicide and Life-Threatening Modernization and socia
Behavior, 30, 163-176.

Steyn, H.S., Jr. (1999). Praktiese beduidendheid: Die gebruik van effekgroottes. Wetenskaplike bydraes, Reeks B: Natuurwetenskappe nr. 117, Potchefstroomse Universiteit vir CHO, Potchefstroom.

Tan, D.L., Morris, L.A., \& Romero, J. (2003). Workable strategies and effectiveness of diversity training. In M.J. Davids \& S.L. Fielden (Eds.). Individual diversity and psychology in organizations (pp. 239-252), John Wiley \& Sons: Chichester: and psychol
England.

Torbiorn, I. (1982). Living Abroad. New York: Wiley.

Van den Broeck, A., Baillien, E., \& De Witte, H. (2011). Workplace bullying: A perspective from the Job Demands-Resources model. South African Journal of Industrial Psychology, 37, 879-891. http://dx.doi.org/10.4102/sajip.v37i2.879

Verkuyten, M. (2005). Ethnic group identification and group evaluation among minority and majority groups: Testing the multicultural hypothesis. Journal of Personality and Social Psychology, 88, 121-138. http://dx.doi.org/10.1037/0022 3514.88.1.121

Verkuyten, M., \& Burug, P. (2004). Multiculturalism and group status: The role of ethnic identification, group essentialism and protestant ethnics. European Journal of Social Psychology, 34, 647-661. http://dx.doi.org/10.1002/ejsp.222

Vertovec, S. (1996). Multiculturalism, culturalism and public incorporation. Ethnic and Racial Studies, 19(1), 49-69. http://dx.doi.org/10.1080/01419870.1996.9993898

Voci, A., \& Hewstone, M. (2003) Intergroup contact and prejudice toward immigrants in Italy: The mediational role of anxiety and the moderational role of group
salience. Group Processes Intergroup Relations, 6(1), 37-54. http://dx.doi. salience. Group Processes Intergroup
org/10.1177/1368430203006001011

Wagner, U., Hewstone, M., \& Machleit, U. (1989). Contact and prejudice between Germans and Turks: A correlational study. Human Relations, 42(7), 561-574. http://dx.doi.org/10.1177/001872678904200701

Walen, H.R., \& Lachman, M.E. (2000). Social support and strain from partner, family, and friends: Costs and benefits for men and women in adulthood. Journal of Social and Personal Relationships, 17, 5-30. http://dx.doi.org/10.1177/0265407500171001

Ward, C., \& Kennedy, A. (2001). Coping with cross-cultural transition. Journal of Cross-Cultural Psychology, 32, 636-42. http://dx.doi. org/10.1177/0022022101032005007

Ward, C., \& Rana-Deuba, A. (1999). Acculturation and adaptation revisited. Journal of Cross-Cultural Psychology, 30, 372-392. http://dx.doi. org/10.1177/0022022199030004003

World Health Organization. (1988). World Health Organization cross-national survey of psychological and somatic symptoms. Geneva, Switzerland: Author.

Xanthopoulou, D., Bakker, A.B., Demerouti, E., \& Schaufeli, W.B. (2009). Work engagement and financial returns: A diary study on the role of job and personal resources. Journal of Organisational and Occupational Psychology, 82, 183-200. http://dx.doi.org/10.1348/096317908X285633

You, S., Van Orden, K.A., \& Conner, K.R. (2010). Social connections and suicidal thoughts and behavior. Psychology of Addictive Behaviors, 25, 180-184. http:// dx.doi.org/10.1037/a0020936 